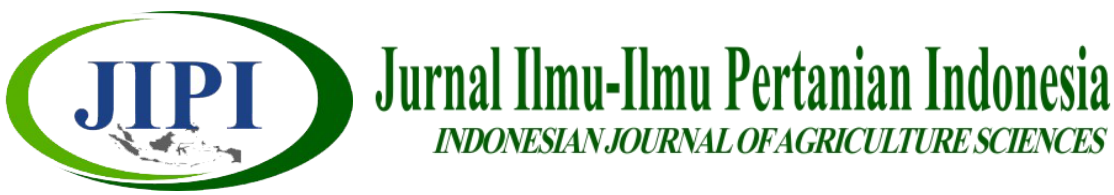

\title{
PERTUMBUHAN DAN HASIL EMPAT VARIETAS KACANG HIJAU (Vigna radiata L.) PADA SISTEM TUMPANGSARI DENGAN BERBAGAI JARAK TANAM JAGUNG
}

\author{
Edhi Turmudi $^{1}$, Nurga Henni Safitri ${ }^{1}$, Widodo $^{1 *}$ \\ ${ }^{1}$ Program Studi Agroekoteknologi, Fakultas Pertanian Universitas Bengkulu \\ * Corresponding Author: widodo@unib.ac.id
}

\begin{abstract}
[GROWTH AND YIELD OF FOUR VARIETIES OF MUNG BEAN (Vigna radiata L.) IN INTERCROPPING SYSTEM WITH VARIOUS CORN PLANT SPACING]. Efforts to increase the productivity of mung beans (Vigna radiata $\mathrm{L}$.) can be done by implementing an intercropping system and using superior varieties. Corn plants need high nitrogen and mung bean plants can fix nitrogen from the free air so that corn plants can take advantage of the excess nitrogen from mung beans. The purpose of this study was to determine the best mung bean varieties in the intercropping system with a various spacing of maize. The research was conducted in October-December 2018, in Pematang Gubernur village, Muara Bangkahulu, Bengkulu. The experiment in this study used a split-plot design with the main plot spacing of maize that was $60 \mathrm{~cm}$ x $30 \mathrm{~cm}, 90 \mathrm{~cm}$ x $30 \mathrm{~cm}, 120 \mathrm{~cm} \times 30 \mathrm{~cm}$, subplots were mung bean varieties (Vima-1, Vima- 2, Vima-3, and Kutilang) with 3 repetitions. Repeated 3 times, then 36 experimental units were obtained. The results showed that the four varieties of mung beans planted intercropping with a various spacing of maize showed different yield responses. Varieties of Vima-1 and Vima-3 gave the highest seed yields at a maize spacing of $60 \mathrm{~cm} \times 30 \mathrm{~cm}$. The Vima-2 variety was at a spacing of $90 \mathrm{~cm} \times 30 \mathrm{~cm}$, while the Kutilang variety was at $120 \mathrm{~cm} \times 30 \mathrm{~cm}$ spacing. The four mung bean varieties were suitable for intercropping with maize with a yield/plot $(\mathrm{NYi})>0.5$.
\end{abstract}

Keyword: plant distance, intercropping, mung bean varieties

\begin{abstract}
ABSTRAK
Upaya peningkatan produktivitas tanaman kacang Hijau (Vigna radiata L.) dapat dilakukan dengan menerapkan sistem tanam tumpangsari dan menggunakan varietas unggul. Tanaman jagung menghendaki nitrogen tinggi dan tanaman kacang hijau dapat memfiksasi nitrogen dari udara bebas, sehingga tanaman jagung dapat memanfaatkan kelebihan nitrogen dari kacang hijau. Tujuan penelitian ini untuk menentukan varietas kacang hijau yang terbaik dalam sistem tumpangsari dengan berbagai jarak tanam jagung. Penelitian dilaksanakan pada bulan OktoberDesember 2018, di Kelurahan Pematang Gubernur, Kecamatan Muara Bangkahulu, Bengkulu. Percobaan dalam penelitian ini menggunakan rancangan petak terbagi (Split Plot) dengan petak utama jarak tanam jagung yaitu $60 \mathrm{~cm}$ x $30 \mathrm{~cm}, 90 \mathrm{~cm}$ x $30 \mathrm{~cm}, 120 \mathrm{~cm}$ x $30 \mathrm{~cm}$, anak petak yaitu varietas kacang hijau (Vima-1, Vima-2, Vima-3, dan Kutilang) dengan 3 ulangan, maka didapatlah 36 satuan percobaan. Hasil penelitian menunjukkan keempat varietas kacang hijau yang ditanam secara tumpangsari dengan berbagai jarak tanam jagung menunjukkan respon hasil biji yang berbeda. Varietas Vima 1 dan Vima 3 memberikan hasil biji tertinggi pada jarak tanam jagung $60 \mathrm{~cm} \times 30 \mathrm{~cm}$. Varietas Vima 2 pada jarak tanam $90 \mathrm{~cm}$ X $30 \mathrm{~cm}$, sedangkan varietas Kutilang pada jarak tanaman jagung $120 \mathrm{~cm}$ x $30 \mathrm{~cm}$. Keempat varietas kacang hijau layak ditanam secara tumpangsari dengan tanaman jagung dengan nilai nisbah hasil/petak $(\mathrm{NYi})>0,5$.
\end{abstract}

Kata kunci: jarak tanam, tumpangsari, varietas kacang hijau 


\section{PENDAHULUAN}

Kacang hijau merupakan termasuk tanaman legume yang banyak peminatnya, dan menepati urutan ketiga setelah tanaman kedelai dan tanaman kacang tanah (Barus et al., 2017 ; Rukmana \& Rahmat. 1997). Kandungan protein yang ada pada kacang hijau sebesar 24\%. Selain itu kacang hijau mengandung karbohidrat, lemak, vitamin, mineral dan serat yang baik (Rahman \& Agus, 2011 ; Holidi et al., 2016).

Upaya peningkatan produktivitas kacang hijau melalui diversifikasi tanaman yaitu dengan sistem pertanaman ganda (Multiple Cropping) yaitu peningkatan produktivitas lahan melalui efesiensi pemanfaatan untuk menghasilkan lebih dari satu jenis tanaman (Aqil et al., 2002). Salah satu bentuk sistem pertanaman ganda adalah penanaman secara tumpangsari (Intercropping), Tumpangsari merupakan sistem pertanaman yang membudidayakan lebih dari satu jenis tanaman yang ditanam pada waktu bersamaan (Putra et al., 2017).

Sistem tumpangsari jagung manis dan kedelai dapat memberikan beberapa keuntungan yaitu efisiensi penggunaan lahan, mengurangi OPT, menambah kesuburan tanah terutama unsur nitrogen, dan mendapatkan hasil tanaman beragam (Aisyah \& Herlina, 2018). Kelebihan system tumpangsari lainnya yaitu dapat menekan laju pertumbuhan gulma, menghemat pemakaian sarana produksi (Lingga et al., 2015). Pola penanaman tumpangsari mempunyai banyak keuntungan di antaranya memperkecil resiko gagal panen pada satu jenis tanaman, mengurangi frekuensi penyiangan, serta memperbaiki konservasi lahan dan air (Warsana, 2009).

Tumpangsari kacang hijau dengan tanaman jagung dapat menguntungkan, karena didasarkan pada perbedaan karakter morfologi dan fisiologi yaitu kedalaman dan distribusi sistem perakaran, bentuk tajuk, laju fotosintesis, pola serapan unsur hara, sehingga diperoleh suatu karakteristik pertumbuhan, perkembangan dan hasil tumpangsari yang bersifat sinergis (Morgodo \& Willey, 2008). Tanaman yang ditumpangsarikan adalah tanaman yang berbeda family, sehingga berbeda dalam kebutuhan zat hara, hama dan penyakit, kepekaaan terhadap toksin dan faktor-faktor lain yang mengendalikan yang sama pada waktu yang berbeda (Lingga et al., 2015 ; Utomo et al., 2017). Selain itu jenis tanaman yang dapat ditumpangsarikan jika dapat memperoleh keuntungan dalam berinteraksi dengan jenis yang lain, tanpa menimbulkan kerugian. Hal ini dapat diketahui dari Nilai nisbah hasilnya (NYij) yaitu nilai perbandingan hasil tanaman pada sistem tumpangsari dibandingkan dengan hasil tanaman pada sistem monokulturnya dengan NYi = Yij/Yii. (Beets, 1982).

Tanaman kacang hijau tergolong tanaman $\mathrm{C}_{3}$ yang bertajuk rendah, fotosintesis berlangsung pada intensitas dan suhu yang relatif lebih rendah sehingga tahan terhadap naungan (Soejono, 1994), sedangkan tanaman jagung tergolong tanaman $\mathrm{C}_{4}$ yang menghendaki pencahayaan penuh untuk berfotosintesis secara efisien dan mampu beradaptasi dengan baik pada faktor pembatas pertumbuhan dan produksi, serta efisien dalam penggunaan air (Goldsworthy \& Fisher, 1984), sehingga kemungkinan persaingan antara kacang hijau dan jagung lebih rendah.

Tingkat kerapatan tanaman berhubungan dengan populasi tanaman dan dapat menentukan hasil. Jumlah populasi tanaman semakin banyak maka akan terjadi peningkatan hasil, tetapi pertambahan jumlah populasi tanaman yang terus menerus akan menurunkan produksi karena adanya kompetisi yang semakin kuat antar tanaman (Aisyah \& Herlina, 2018).

Pemilihan varietas juga menjadi faktor yang penting karena potensi genetik akan menentukan hasil. Pengelolaan kondisi di lingkungan dengan faktor genetik dapat mempengaruhi produksi. Potensi hasil yang tinggi dari varietas tidak akan tercapai, bila pengelolaan lingkungannya tidak dilakukan dengan baik (Sinaga et al., 2017).

Secara garis besar yang membedakan dari setiap varietas yaitu tinggi tanaman, bobot 100 biji, umur panen, dan rata-rata hasil. Varietas Kutilang memiliki tinggi tanaman 53-60 cm, bobot 100 biji sebesar 6,0-7,0 g, waktu panen 60-67 hari, dan rata-rata hasil 1,1,3 ton/ ha. Varietas Vima-1 memiliki tinggi tanaman $53 \mathrm{~cm}$, bobot 100 biji $6,3 \mathrm{~g}$, umur panen 57 hari, dan ratarata hasil 1,38 ton/ha. Varietas Vima-2 memiliki tinggi tanaman $\pm 64,3 \mathrm{~cm}$, bobot 100 biji $6,6 \mathrm{~g}$, umur panen 56 hari, dan rata-rata hasil $\pm 1,8$ ton/ha. Varietas Vima-3 memiliki tinggi tanaman $\pm 75,3 \mathrm{~cm}$, bobot $100 \mathrm{biji}$ $5,9 \mathrm{~g}$, umur panen 60 hari, dan rata-rata hasil 1,8 ton/ ha (Balitkabi. 2012 ; Balai Penelitian Tanaman Aneka Kacang dan Umbi, 2016).

Produksi kacang hijau dapat ditingkatkan selain menggunakan penerapan sistem tanam tumpangsari memerlukan varietas yang sesuai karena varietas kacang hijau memiliki karateristik yang berbeda-beda sehingga apabila ditanam dengan tanaman jagung, maka akan memiliki pertumbuhan dan hasil yang berbeda-beda pula. Beberapa varietas kacang hijau yang telah dikeluarkan oleh Balitkabi antara lain Vima-1, Vima-2, Vima-3, dan Kutilang (Balitkabi, 2012). Penelitian ini diharapkan mendapatkan varietas yang cocok ditanam dalam sistem tumpangsari pada berbagai jarak tanam jagung.

Tujuan penelitian ini untuk menentukan varietas kacang hijau yang cocok dalam sistem tumpangsari pada berbagai jarak tanam jagung.

\section{METODE PENELITIAN}

Penelitian ini dilaksanakan pada bulan Oktober sampai Desember 2018, yang berlokasi di lahan pertanian dengan jenis tanah Ultisol di wilayah Kelurahan Pematang Gubernur, Kecamatan Muara Bangkahulu, kota Bengkulu. Lahan percobaan memiliki ketinggian 22 $m$ dpl dengan jenis tanah Ultisol. 
Rancangan percobaan yang digunakan adalah Rancangan Petak Terbagi (Split-Plot Design) yang terdiri atas tiga petak utama dengan empat anak petak yang diulang sebanyak tiga kali. Petak utama yaitu berbagai jarak tanam jagung yang terdiri atas $\mathrm{J}_{1}$ (jarak tanam $60 \mathrm{~cm} \times 30 \mathrm{~cm}$ ), $\mathrm{J}_{2}$ (jarak tanam 90 $\mathrm{cm} \times 30 \mathrm{~cm}), J_{3}($ jarak tanam $120 \mathrm{~cm}$ x $30 \mathrm{~cm}$ ) dan anak petak yaitu jenis varietas kacang hijau yang terdiri dari $\mathrm{V}_{1}$ (Vima-1), $\mathrm{V}_{2}$ (Vima-2), $\mathrm{V}_{3}$ (Vima3), dan $\mathrm{V}_{4}$ (Kutilang).

Bahan yang digunakan yaitu benih jagung Pertiwi 3, benih kacang hijau varietas (Vima-1, Vima-2, Vima-3, dan Kutilang), pupuk Urea, pupuk TSP, pupuk $\mathrm{KCl}$, dan fungisida yang berbahan aktif Mankozeb $80 \%$.

Tahapan penelitian meliputi persiapan lahan, penanaman, pemupukan, pemeliharaan tanaman, dan panen. Penanaman jagung pada sistem tumpangsari sesuai dengan perlakuan, yaitu perlakuan $\mathrm{J}_{1}$ (jarak tanam $60 \mathrm{~cm} \times 30 \mathrm{~cm}$ ), perlakuan $J_{2}$ (jarak tanam $90 \mathrm{~cm} \times 30 \mathrm{~cm}$ ), perlakuan $J_{3}$ (jarak tanam $120 \mathrm{~cm}$ x $30 \mathrm{~cm}$ ).Penanaman kacang hijau dilakukan sesuai jarak tanam yaitu $30 \mathrm{~cm} \times 30 \mathrm{~cm}$, dan pada sistem tumpangsari, tanaman kacang hijau ditanam dalam antarbarisan jagung. Lubang tanam dibuat dengan tugal sedalam $3 \mathrm{~cm}$. Benih jagung dan kacang hijau (yang sebelumnya telah direndam air hangat selama 30 menit) ditanam dengan cara benih dimasukkan pada setiap lubang tanam yang terdiri 2 benih pada lahan tumpangsari, dan 3 benih pada lahan monokultur dan diberi karbofuran 3\%. Pemupukan Urea pada tumpangsari dilakukan dua kali dengan dosis total $175 \mathrm{~kg} / \mathrm{ha}$ sebesar $189 \mathrm{~g} /$ petak. Pemupukan pertama dilakukan saat 1 MST dengan $1 / 2$ dosis total sebanyak $94,5 \mathrm{~g} /$ petak dan pemupukan kedua diberikan saat umur 5 MST dengan $1 / 2$ dosis total sebanyak 94,5 g/petak. Sedangkan pemupukan TSP dengan dosis total $225 \mathrm{~kg} / \mathrm{ha}$ sebanyak $243 \mathrm{~g} /$ petak dan $\mathrm{KCl}$ dengan dosis total $75 \mathrm{~kg} / \mathrm{ha}$ sebanyak 81 g/petak diberikan satu kali pada umur 1 MST. Pemupukan dilakukan dengan cara dibuat alur pada petakan, kemudian pupuk ditebar dan selanjutnya ditutup dengan tanah. Panen polong kacang hijau dilakukan ketika telah memenuhi kriteria panen. Kriteria panen kacang hijau polong telah masak yaitu berubahnya warna polong dari hijau menjadi hitam (Balai Penelitian Tanaman Aneka Kacang dan Umbi, 2016). Panen dilakukan dengan cara dipetik bagian tangkai polong. Polong yang telah kering dimasukkan ke dalam karung dipukul-pukul dengan hati-hati sampai kulit polong pecah dan dilakukan pemisahan biji dari kulit menggunakan tampi.

Data hasil pengamatan selanjutnya dianalisis secara statistik menggunakan analisis varian pada taraf 5\%. Jika data yang diperoleh menunjukkan hasil yang berbeda nyata antar perlakuan, dilanjutkan uji rata-rata DMRT taraf 5\%.

\section{HASIL DAN PEMBAHASAN}

Secara umum hasil penelitian ini menunjukkan tidak terjadi interaksi yang nyata antara jarak tanaman jagung dan varietas kacang hijau pada kebanyakan variabel pertumbuhan maupun hasil tanaman kacang hijau, kecuali pada variabel bobot brangkasan/tanaman dan hasil biji/petak (Tabel 1). Hal ini dapat diartikan bahwa keempat varietas tanaman kacang hijau menunjukkan respon yang berbeda tidak nyata terhadap jarak tanaman jagung pada kebanyakan variabel pertumbuhan tanaman. Demikian halnya perlakuan jarak tanam jagung juga tidak memberikan pengaruh nyata terhadap sebagian besar variabel, pertumbuhan dan hasil tanaman kacang hijau, kecuali pada variabel bobot brangkasan/tanaman. Sedangkan di antara keempat varietas tanaman kacang hijau menunjukkan ada perbedaan yang nyata pada variabel pengamatan tinggi tanaman, jumlah daun, tingkat kehijauan daun, bobot kering brangkasan, bobot 100 biji dan bobot biji/petak, namun berbeda tidak nyata pada variabel pengamatan jumlah polong/ tanaman, dan bobot biji/tanaman.

Tabel 1. Rangkuman hasil analisis varians peubah pertumbuhan dan hasil tanaman kacang hijau pada sistem tumpangsari

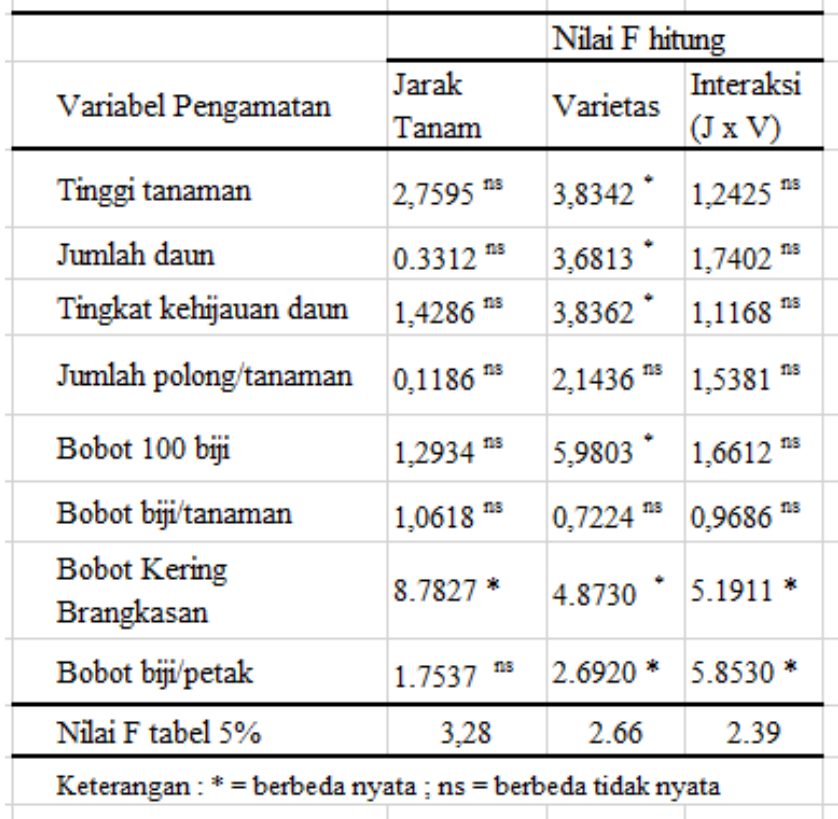

Pertumbuhan tinggi tanaman kacang hijau secara umum sesuai dengan data deskripsi kacang hijau dari Balitkabi Malang. Perbedaan antara varietas pada kebanyakan variabel pengamatan, menunjukkan bahwa di antara keempat varietas memiliki sifat genetik yang berbeda. Penampilan pertumbuhan tanaman sebagai sifat Fenotipe merupakan hasil interaksi antara faktor lingkungan dengan faktor genetik. Oleh karena itu pengaruh dari faktor genetik dan lingkungan dapat 
menyebabkan perbedaan pertumbuhan di antara keempat varietas tanaman kacang hijau. Faktor genetik yang cukup kuat menyebabkan penampilan pertumbuhan kacang hijau lebih ditentukan oleh potensi gen yang dimiliki. Kondisi lingkungan curah hujan, cahaya matahari, suhu, kelembaban yang telah sesuai dengan syarat hidupnya, menyebabkan tanaman dapat tumbuh secara normal. Rukmana \& Rahmat (1997) menjelaskan bahwa syarat tumbuh tanaman kacang hijau harus memiliki iklim rata-rata curah hujan $50-200 \mathrm{~mm} /$ bulan, suhu $25-27^{\circ} \mathrm{C}$, dan kelembaban udara $50-80 \%$. Hal ini telah sesuai dengan data iklim Badan Meteorologi Klimatologi dan Geofisika saat penelitian.

Bobot brangkasan merupakan bobot biomassa tanaman tanpa mengikut-sertakan bobot biji. Dengan demikian bobot brangkasan merupakan biomassa organ vegetatif tanaman (Sitompul \& Guritno, 1995). Pada siklus perkembangan tanaman, organ vegetatif terbentuk lebih dahulu, karena diperlukan untuk mendukung terbentuknya organ generatif berupa biji (Goldsworthy \& Fisher. 1984). Pada sistem kehidupan tanaman, biji merupakan alat untuk perkembangbiakan secara generatif. Akan tetapi biji juga dimanfaatkan oleh manusia untuk dikonsumsi sebagai bahan pangan, sehingga biji tanaman kacang hijau disebut juga produk ekonomis,

Empat varietas tanaman kacang hijau pada sistem tumpangsari memberikan respon bobot brangkasan tanaman jagung yang berbeda terhadap perlakukan jarak tanam jagung (Tabel 2). Varietas Vima-3 secara umum menghasilkan bobot brangkasan yang lebih tinggi dibandingkan dengan Vima-1. Varietas Vima-2 menghasilkan bobot brangkasan tertinggi pada jarak tanam jagung $90 \mathrm{~cm} \times 30 \mathrm{~cm}$, demikian juga untuk varietas Kutilang, meskipun dengan jarak tanam jagung $60 \mathrm{~cm} \times 30 \mathrm{~cm}$ bobot brangkasanya tidak berbeda. Varietas Vima-1 tampak memiliki toleransi terhadap naungan dan ketahanan bersaing dengan tanaman jagung yang lebih rendah jika dibandingkan dengan varietas Vima-2, Vima-3 maupun Kutilang. Varietas Vima-2 memperlihatkan tingkat kepekaan yang tinggi terhadap penaungan maupun kompetisi dengan tanaman jagung. Pada jarak tanam jagung yang lebih rapat maupun maupun lebih renggang varietas Vima-2 menunjukkan penurunan bobot brangkasan yang nyata dibandingkan dengan pada jarak tanam jagung sedang $(90 \mathrm{~cm}$ x 30 $\mathrm{cm})$. Sebaliknya terjadi pada varietas Vima-3 yang menghasilkan bobot brangkasan terendah justru pada jarak tanaman jagung $90 \mathrm{~cm}$ x $30 \mathrm{~cm}$. Varietas Kutilang merupakan_varietas kacang hijau yang cocok dengan tingkat penaungan cukup tinggi, karena pada jarak tanaman jagung yang sempit $(60 \mathrm{~cm} \times 30 \mathrm{~cm})$ menghasilkan bobot brangkasan lebih tinggi dibandingkan pada jarak tanam jagung yang lebih lebar (120 cm x $30 \mathrm{~cm})$.
Tabel 2. Interaksi antara jarak tanam jagung dan varietas kacang hijau terhadap bobot brangkasan (g/tanaman)

\begin{tabular}{|c|c|c|c|c|}
\hline \multirow{2}{*}{ No. } & \multirow{2}{*}{$\begin{array}{c}\text { Varietas } \\
\text { tanaman } \\
\text { Kacang } \\
\text { Hijau }\end{array}$} & \multicolumn{3}{|c|}{ Jarak Tanam Jagung } \\
\hline & & $60 \mathrm{~cm} \times 30 \mathrm{~cm}$ & $90 \mathrm{~cm} \times 30 \mathrm{~cm}$ & $120 \mathrm{~cm} \times 30 \mathrm{~cm}$ \\
\hline \multirow[t]{2}{*}{1} & Vima 1 & $2,8283 b$ & $3,4127 b$ & 4,4816 bc \\
\hline & & B & $A B$ & A \\
\hline \multirow[t]{2}{*}{2} & Vima 2 & $2,3572 b$ & 7,6455 a & $3,4883 \mathrm{c}$ \\
\hline & & B & A & B \\
\hline \multirow[t]{2}{*}{3} & Vima 3 & $7,2433 a$ & $5,8316 a b$ & $8,9961 \mathrm{a}$ \\
\hline & & $A B$ & B & A \\
\hline \multirow[t]{2}{*}{4} & Kutilang & $6,1850 a b$ & 6,6955 a & $5,1583 \mathrm{~b}$ \\
\hline & & A & $\mathrm{A}$ & $\mathrm{B}$ \\
\hline \multicolumn{5}{|c|}{ Keterangan : Angka-angka yang diikuti oleh huruf yang sama berbeda } \\
\hline \multicolumn{5}{|c|}{ tidak nyata pada DMRT $5 \%$. Huruf kapital dibaca ke arah baris, dan huruf } \\
\hline \multicolumn{3}{|c|}{ kecil dibaca ke arah kolom } & & \\
\hline
\end{tabular}

Perbedaan respon bobot brangkasan dari keempat varietas tanaman kacang hijau terhadap variasi jarak tanam jagung menunjukkan adanya perbedaan sifat genetik antar varietas dalam merespon variasi kondisi lingkungan. Respon tanaman kacang hijau terhadap jarak tanam jagung kemungkinan berhubungan dengan efisiensi pemanfaatan cahaya matahari yang digunakan untuk proses fotosintesis. Tanaman kacang hijau termasuk golongan tanaman yang proses fotosintesisnya melalui jalur C3 (Goldsworthy \& Fisher. 1984). Pada umumnya jenis tanaman ini cukup toleran terhadap penaungan sehingga efisien dalam pemanfaatan cahaya dengan intensitas yang rendah akibat penaungan (Lambers \& Oliveira, 2019). Hasil penelitian ini sejalan dengan hasil penelitian Aisyah \& Herlina. (2018) yang menunjukkan bahwa dalam sistem tumpangsari, varietas kedelai memberikan respon pertumbuhan dan hasil yang berbeda terhadap jarak tanaman jagung.

Bobot biji/petak merupakan ukuran produk ekonomis yang dihasilkan oleh sistem pertanaman dengan satuan gram per satuan luas petakan (g/petak) atau dapat disetarakan menjadi ton/hektar. Bobot biji/ petak yang dihasilkan oleh keempat varietas kacang hijau dalam sistem tumpangsari dengan tiga jarak tanam jagung (Tabel 3).

Varietas Vima-1 dan Vima-3 menunjukkan hasil tertinggi pada tumpangsari dengan jarak tanam jagung sempit $(60 \mathrm{~cm}$ x $30 \mathrm{~cm})$. Hal ini menunjukkan kedua varietas ini tahan terhadap penaungan yang cukup rapat oleh tanaman jagung. Berbeda dengan varietas Vima 2 memberikan hasil bobot biji tertinggi pada jarak tanam jagung sedang $(90 \mathrm{~cm} \times 30 \mathrm{~cm})$ yang berbeda nyata dengan pada jadak tanam jagung $60 \mathrm{~cm} \times 30$ $\mathrm{cm}$ maupun $120 \mathrm{~cm}$ x $30 \mathrm{~cm}$. Hal ini menunjukan Vima-2 memikili kepekaan respon yang cukup tinggi terhadap cahaya matahari. Sebaliknya Kutilang memberikan hasil bobot biji tertinggi pada jarak tanam jagung yang lebar $(120 \mathrm{~cm}$ x $30 \mathrm{~cm})$, artinya varietas Kutilang lebih kurang tahan terhadap penaungan. 
Tabel 3. Interaksi antara jarak tanam jagung dan varietas kacang hijau terhadap bobot biji/petak

\begin{tabular}{|c|c|c|c|c|}
\hline \multirow{2}{*}{ No. } & \begin{tabular}{c} 
Varietas \\
tanaman \\
\cline { 3 - 5 }
\end{tabular} & \multicolumn{3}{|c|}{ Jarak Tanam Jagung } \\
\cline { 3 - 5 } & Kacang & $60 \mathrm{~cm} \times 30 \mathrm{~cm}$ & $90 \mathrm{~cm} \times 30 \mathrm{~cm}$ & $120 \mathrm{~cm} \times 30 \mathrm{~cm}$ \\
\hline 1 & Vima-1 & $725,7333 \mathrm{a}$ & $634,9000 \mathrm{~b}$ & $549,7667 \mathrm{~b}$ \\
\hline & & $\mathrm{A}$ & $\mathrm{AB}$ & $\mathrm{B}$ \\
\hline 2 & Vima-2 & $600,0000 \mathrm{~b}$ & $730,0000 \mathrm{a}$ & $360 \mathrm{c}$ \\
\hline & & $\mathrm{B}$ & $\mathrm{A}$ & $\mathrm{C}$ \\
\hline 3 & Vima-3 & $780,0000 \mathrm{a}$ & $606,6667 \mathrm{~b}$ & $626,6667 \mathrm{a}$ \\
\hline & & $\mathrm{A}$ & $\mathrm{B}$ & $\mathrm{B}$ \\
\hline 4 & Kutilang & $546,6667 \mathrm{~b}$ & $470,0000 \mathrm{c}$ & $693,3333 \mathrm{a}$ \\
\hline & & $\mathrm{AB}$ & $\mathrm{B}$ & $\mathrm{A}$ \\
\hline
\end{tabular}

Keterangan : Angka-angka yang diikuti oleh huruf yang sama berbeda tidak nyata pada DMRT 5\%. Huruf kapital dibaca ke arah baris, dan huruf kecil dibaca ke arah kolom

Berdasarkan data respon bobot brangkasan dan bobot biji/tanaman dari setiap varietas kacang hijau (data pada Tabel 2 dan Tabel 3) dapat diketahui bahwa Vima-1, Vima-3 dan Kutilang menunjukkan respon yang berlawanan antara bobot brangkasan/ tanaman dengan bobot biji/petak terhadap jarak tanam jagung. Varietas Vima 1 dan Vima 3 menunjukkan bobot bangkasan/tanaman tertinggi dihasilkan pada jarak tanaman jagung yang lebar yaitu $120 \mathrm{~cm} \times 30 \mathrm{~cm}$. Akan tetapi hasil bobot biji/petak dihasilkan pada jarak tanaman jagung yang sempit $(60 \mathrm{~cm} \times 30 \mathrm{~cm})$, sedangkan varietas Kutilang adalah sebaliknya. Hubungan yang berlawanan antara bobot brangkasan dan bobot biji/petak diduga pada fase pengisian biji terjadi translokasi biomassa yang intensif dari organ vegetatif ke biji. Hal ini menyebabkan organ vegetatif terutama daun banyak yang spontan mengalami peluruhan dan gugur pada tanaman yang bobot bijinya tinggi. Hal yang berbeda pada varietas Vima-2 bobot brangkasan/ tanaman maupun bobot biji/petak dihasilkan pada jarak tanam jagung yang sedang $(90 \mathrm{~cm} \times 30 \mathrm{~cm})$. Varietas Vima-2 diduga mempunyai proses translokasi biomassa dari organ vegetatif ke biji berlangsung secara seimbang. Proses pengisian biji berlangsung pada akhir fase generatif. Pada tanaman semusim proses ini berjalan intersif, dan berlangsung dalam waktu yang singkat, sehingga mengakibatkan peluruhan sebagian besar organ vegetatif terutama daun. Hasil penelitian yang dilaporkan Lingga et al. (2015) menunjukkan ada perbedaan hasil biji antar varietas kacang hijau pada sistem tumpangsari dengan jagung manis.

Varietas Vima-3 menunjukkan penampilan pertumbuhan vegetatif tinggi tanaman, jumlah daun tingkat kehijauan daun dan bobor kering tanaman yang lebih tinggi dibandingkan dengan ketiga varietas yang lain Akan tetapi bobot 100 biji yang dihasilkan oleh varietas Vima-3 justru paling rendah (Tabel 4).. Hal ini tidak sesuai dengan pendapat Hakim \& Suryamto. (2012) bahwa terdapat korelasi yang positif antara pertumbuhan organ vegetatif dengan pertumbuhan generatif. Varietas Vima-3 menghasilkan rata-rata ukuran biji yang paling kecil. Varietas Vima-1 dan Vima-2 secara konsisten memperlihatkan ukuran pertumbuhan vegetatif maupun generatif yang rendah. Sebaliknya varietas Kutilang, meskipun ukuran variabel pertumbuhan vegetatif yang rendah, tetapi ukuran bobot 100 bijinya tertinggi di antara ketiga varietas yang lainnya.

Tabel 4. Perbedaan antar varietas pada pertumbuhan dan hasil tanaman kacang hijau

\begin{tabular}{|c|c|c|c|c|c|}
\hline Varietas & $\begin{array}{c}\text { Tinggi } \\
\text { tanaman } \\
(\mathrm{cm})\end{array}$ & $\begin{array}{l}\text { Jumlah } \\
\text { daun }\end{array}$ & $\begin{array}{l}\text { Tingkat } \\
\text { kehijaun } \\
\text { daun }\end{array}$ & $\begin{array}{l}\text { Bobot kering } \\
\text { tanaman }(\mathrm{g})\end{array}$ & $\begin{array}{c}\text { Bobot } \\
100 \text { biji } \\
\text { (g) }\end{array}$ \\
\hline Vima 1 & $33,40 \quad b$ & $5,75 \quad b$ & $45,87 \mathrm{ab}$ & $2,76 \mathrm{~b}$ & $6,79 \mathrm{bc}$ \\
\hline Vima 2 & $34,20 \quad b$ & 5,62 b & $42,80 \mathrm{~b}$ & $3,05 \mathrm{~b}$ & $7,07 \mathrm{~b}$ \\
\hline Vima 3 & 46,06 a & 6,30 a & $51,08 \mathrm{a}$ & $4,15 \mathrm{a}$ & $6,60 \mathrm{c}$ \\
\hline Kutilang & $38,53 \mathrm{~b}$ & $5,78 \quad b$ & $48,25 \mathrm{ab}$ & $3,54 \mathrm{ab}$ & $7,97 \mathrm{a}$ \\
\hline
\end{tabular}

Keterangan : Angka-angka yang diikuti oleh huruf yang sama pada kolom yang sama berbeda tidak nyata pada DMRT $5 \%$.

Perbedaan ukuran pertumbuhan dan hasil antar varietas membuktikan bahwa antar varietas memiliki keragaman genetik yang berbeda-beda. Setiap varietas terpilih memliki keunggulan sifat genetik tertentu. Faktor genetik merupakan sifat bawaan yang diturukan ke genetasinya. Tampilan pertumbuhan tanaman merupakan hasil interaksi antara potensi genetik yang dimiliki dengan kondisi lingkungan yang ada.

Nisbah hasil merupakan nilai perbandingan hasil tanaman pada sistem tumpangsari dibandingkan dengan hasil tanaman pada sistem monokulturnya. Nilai nisbah hasil dapat digunakan sebagai dasar dalam menentukan suatu jenis tanaman cocok atau tidak untuk ditanam secata tumpangsari. Nilai nisbah hasil dapat dihitung dari data hasil/tanaman dengan menghasilkan nilai Nisbah hasil pertanaman (Nyi) yaitu perbandingan ukuran hasil tanaman i per individu pada sistem tumpangsari dengan hasil monokulturnya. Atau dinyatakan dalam rumus

Nyi $=\frac{\text { Yij per individu }}{\text { Yii per individu }}$

Tanaman jenis i cocok ditanam secara tumpangsari dengan tanaman jenis j, jika nilai (Nyi) $>1$. Dengan demikian hasil per individu jenis i pada sistem tumpangsari (Yij) lebih besar dari hasil per individu jenis i pada sistem monokulturnya (Yii). Hal ini menunjukkan bahwa tanaman jenis i dapat memperoleh keuntungan dari hasil interaksi dengan jenis tanaman lain yang ditumpangsarikan.

Nisbah hasil tanaman i per petak (NYi) adalah perbandingan ukuran hasil tanaman i per satuan luas 
pada sistem tumpangsari dengan hasil monokulturnya pada satuan luasan yang sama.atau dengan rumus :

$$
\mathrm{NY}_{\mathrm{i}}=\frac{\text { Yij per petak }}{\text { Yii per petak }}
$$

Tanaman jenis i cocok ditanam secara tumpangsari dengan tanaman jenis $\mathrm{j}$, jika nilai nisbah hasil per petak $(\mathrm{NYi})>0.5$ Nilai nisbah hasil per petak $(\mathrm{NYi})$ $=0,5$ artinya hasil tanaman jenis i seluas 0,5 bagian pada tumpangsri setara dengan hasil tanaman jenis $\mathrm{i}$ seluas 1 pada monokulturnya (Beets, 1982).

Varietas Vima-3 dan Kutilang pada sistem tumpangsari dengan tanaman jagung menghasilkan bobot brangkasan/tanaman yang lebih tinggi dari sistem monokulturnya dengan nilai Nyi masing-masing sebesar 1,2598 dan 1,2207 (Tabel 5). Hal ini dapat diartikan bahwa tanaman kacang hijau varietas Vima 3 dan Kutilang dapat memperoleh keuntungan dari hasil interaksi dengan tanaman jagung yang ditumpangsarikan. Sedangkan varietas Vima-1 dan Vima-2 dengan nilai Nyi bobot brangkasan/tanaman masing-masing sebesar 0,8865 dan 0,9699 yang menunjukkan varietas ini mengalami kerugian di dalam berinteraksi dengan tanaman jagung pada sistem tumpangsarinya, sehingga kurang cocok ditumpangsarikan dengan tanaman jagung.

Namun demikian berdasarkan data bobot biji/ petak (data pada Tabel 5), nisbah hasil/ petak keempat varietas kacang hijau menghasilkan nilai (NYi) > 0,5, Dengan demikian berdasarkan hasil biji/petak, keempat varietas kacang hijau yaitu Vima-1, Vima2, Vima-3 maupun Kutilang dapat ditumpangsarikan dengan tanaman jagung. Hal ini didasarkan pada nilai kesetaraannya lebih dari 0,5 . Pada sistem ini menunjukkan keempat varietas dapat menghasilkan biji/tanaman lebih besar dari pada sistem monokulturnya. Tanaman kacang hijau yang proses fotosintesisnya melalui jalur C3 memiliki sifat tidak tahan terhadap pencahayaan penuh, karena dapat terjadi fotorespirasi. Proses ini akan menurunkan hasil fotosintesis, sehingga dapat menghambat pertumbuhan dan berakibat pada penurunan hasil tanaman. Adanya penaungan dari tajuk tanaman jagung dalam sistem tumpangsri, dapat menguntungkan bagi tanaman kacang hijau.

Pada penelitian ini keempat varietas yang ditanaman secara tumpangsari memberikan hasil biji/ petak atau setara dengan per hektar untuk varietas Vima-1, Vima-2, Vima-3 dan Kutilang sebesar 0.53 ton/ha; 0,47 ton/ha; 0,56 ton/ha dan 0,47 ton/ha. Sedangkan pada sistem monokulturnya masingmasing 0,83 ton/ha, 0,70 ton/ha; 0,96 ton/ha dan 0,91 ton/ha. Hasil ini tergolong rendah, karena hasil ratarata berdasarkan deskrisi keempat varietas tersebut berkisar antara 1,1 ton/ha sampai dengan 1,8 ton/ha (Balitkabi. 2012). Rendahnya hasil tanaman kacang hijau ini diduga lahan yang digunakan merupakan lahan marjinal dengan tingkat kesuburan yang rendah. Selain itu pada fase generatif, tanaman kacanghijau terserang oleh penyakit karat daun. Hasil tanaman sangat dipengaruhi oleh kondisi lingkungan, terutama kesuburan tanah dan gannguan oleh hama maupun penyakit tanaman (Aqil et al,.2002

Tabel 5. Rata-rata nilai nisbah hasil bobot brangkasan/tanaman dan hasil biji/petak empat varietas kacang hijau

\begin{tabular}{|c|c|c|c|c|c|c|}
\hline \multirow{2}{*}{$\begin{array}{c}\text { Varietas } \\
\text { Kacang Hijau }\end{array}$} & \multicolumn{2}{|c|}{ Bobot brangkasan/tanaman (g) } & \multirow{2}{*}{$\begin{array}{c}\text { Nisbah } \\
\text { hasil } \\
\text { tanaman } \\
\text { (Nyi) }\end{array}$} & \multicolumn{2}{|c|}{ Bobot biji/petak (g) } & \multirow{2}{*}{$\begin{array}{l}\text { Nisbah hasil/ } \\
\text { petak (NYi) }\end{array}$} \\
\hline & Tumpangs: & Monokultur (Yii) & & Sistem Tumpangsari (Yij) & Monokultur (Yii) & \\
\hline Vima-1 & 4,6485 & 5,2431 & 0,8865 & 636,8 & 995,7361 & 0,6395 \\
\hline Vima-2 & 5,6588 & 5,8339 & 0,9699 & 563,3333 & 840,8962 & 0,6699 \\
\hline Vima-3 & 8,9855 & 7,1323 & 1,2598 & 671,1111 & 1157,8816 & 0,5796 \\
\hline Kutilang & 7,5325 & 6,1702 & 1,2207 & 570 & 1096,2538 & 0,5199 \\
\hline
\end{tabular}




\section{KESIMPULAN}

Berdasarkan hasil dan pembahasan, dapat disimpul kan bahwa: Keempat varietas kacang hijau yang ditanam secara tumpangsari dengan berbagai jarak tanam jagung menunjukkan respon hasil biji yang berbeda. Varietas Vima-1 dan Vima-3 memberikan hasil biji tertinggi pada jarak tanam jagung $60 \mathrm{~cm} \times 30 \mathrm{~cm}$. Varietas Vima-2 pada jarak tanam $90 \mathrm{~cm}$ x $30 \mathrm{~cm}$, sedangkan varietas Kutilang pada jarak tanaman jagung $120 \mathrm{~cm} \mathrm{x}$ $30 \mathrm{~cm}$. Keempat varietas kacang hijau layak ditanam secara tumpangsari dengan tanaman jagung dengan nilai nisbah hasil/petak $(\mathrm{NYi})>0,5$. Rata-rata hasil biji/satuan luas dari keempat varietas pada sistem tumpangsari dengan jagung maupun monokulturnya tergolong rendah, karena hasil rata-rata tertinggi pada sistem tumpangsari hanya mencai 0,56 ton/ha, sedangkan pada monokulturnya sebesar 0,96 ton/ha, Hasil rata-rata berdasarkan deskripsi keempat varietas tersebut berkisar antara 1,1 ton/ha sampai dengan 1,8 ton/ha.

\section{DAFTAR PUSTAKA}

Aisyah, Y. \& Herlina, N. (2018). Pengaruh jarak tanam jagung manis (Zea mays L. var. saccharata) pada tumpangsari dengan tiga varietas tanaman kedelai(Glycine max L.). Jurnal Produksi Tanaman, 6(1), 66-75.

Aqil, M., Firmansyah \& Prabowo, A. (2002). Analisis Pola Tanam Palawija Pada Agroklimat Lahan Tadah Hujan. In Tastra IK, Soejitno J, Sudaryono, Arsyad DM, Suharsono, Sudarjo, Heriyanto, Utomo JS, Taufig A (eds.). Prosiding Seminar Nasional Peningkatan Produktivitas, Kualitas, Efisiensi dan Sistem Produksi Tanaman KacangKacangan dan Umbi-Umbian Menuju Ketahanan Pangan dan Pengembangan Agribisnis. Puslitbangtan, Badan Litbang Pertanian, Bogor.

Balitkabi. (2012). Deskripsi varietas unggul kacangkacangan dan umbi-umbian. Balai Penelitian Tanaman Aneka Kacang dan Umbi, Malang.

Balai Penelitian Tanaman Aneka Kacang dan Umbi. (2016). Penanganan Panen dan Pasca Panen. Agro Inovasi, Malang.

Barus, W. A., Khair, H. \& Siregar, M.A. (2017). Respon pertumbuhan dan produksi kacang hijau (Phaseolus radiates L.) akibat penggunaan pupuk organik cair dan pupuk TSP. Agrium, 19(1), 1-11.

Beets, W.C. (1982). Multiple Cropping and Tropical Farming Systems. Gower Publishing Co., Colorado.

Goldsworthy, P.R. \& Fisher, N.M. (1984). The Physiology of Tropical Field Crops. Jhon Willey \& Sons, Ltd., New York.
Hakim, L. \& Suryamto. (2012). Korelasi antarkarakter dan sidik lintas antara komponen hasil dengan hasil biji kacang hijau (Vigna radiata L.). Berita Biologi, 11(3), 339-349. DOI:https://10.14203/beritabiologi. v1 1i3.504.

Holidi, H., Bahri, S. \& Karno. (2016). Pertumbuhan dan Produksi Tiga Varietas Kacang Hijau (Vigna radiata L.) di Tanah Gambut dan Mineral. Prosiding Seminar Nasional Lahan Suboptimal.

Lambers, H. \& Oliveira, R.S. (2019). Plant Physiological Ecology Third Edition. Springer Nature Switzerland AG. DOI: https:// doi.org/10.1007/978-3-030-29639-1.

Lingga, G. K., Purwanti, S. dan Toekidjo. (2015). Hasil dan kualitas benih kacang hijau (Vigna radiata (L.) Wilczek) tumpangsari barisan dengan jagung manis (Zea mays Saccharata). Jurnal Vegetalika, 4(2), 39-47.

Morgodo, L.B. \& Willey, R.W. (2008). Optimum plant population for maize-bean intercropping system in the Brazillian Semi-Arid Region. Sci. Agric, 65, 474-480.

Putra, J. P. H, K. P. Wicaksono \& Herlina, N. (2017). Studi sistem tumpangsari jagung (Zea mays L.) dan bawang prei (Allium porrum L.) pada berbagai jarak tanam. Jurnal Produksi Tanaman. 5(5), 748-755.

Rahman, T. \& Agus, T. (2011). Pemanfaatan kacang hijau (phaseolus radiatus L) menjadi susu kental manis kacang hijau. Prosiding Seminar Nasional Sains dan Teknologi, 2(1), pp.223230.

Rukmana \& Rahmat. (1997). Kacang Hijau, Budidaya dan Pasca Panen. Kanisius, Jakarta.

Sitompul, S.M., \& Guritno, B. (1995). Analisis Pertumbuhan Tanaman. Gadjah Mada University Press, Yogyakarta.

Soejono, A. T. (1994). Pertumbuhan dan hasil beberapa jenis tanaman kacang dalam tumpangsari dengan rebon rotoon. Laporan Penelitian Fakultas Pertanian Universitas Gadjah Mada, Yogyakarta.

Utomo, W., Astiningrum, M. \& Susilowati, Y.E. (2017). Pengaruh mikoriza dan jarak tanam terhadap hasil tanaman jagung manis (Zea mays var. Saccharata Sturt). Jurnal Ilmu Pertanian Tropika dan Subtropika. 2(1), 2833.

Warsana.(2009). Introduksi teknologi tumpangsari jagung dan kentang. Bul. Penel., 45(7), 9-12. 